DOI: $10.2478 /$ ausp-2014-0006

\title{
Appeal to the Witness. The Role of Romanian Post-Communist Witness Literature in Outlining National (Self-)Images
}

\author{
Laura SASU \\ Transilvania University of Braşov \\ Department of Theoretical and Applied Linguistics \\ laurasasu@yahoo.com
}

\begin{abstract}
The purpose of this paper is to identify and investigate the role of Romanian post-communist witness literature for contemporary historiography in outlining national and social (self-)images. This type of literature, written mostly by former political detainees, is perceived by literary criticism as a specific borderline segment partly relevant as historical documents and partly as literary texts. Applying the conceptual pattern coined by Giorgio Agamben, in his analysis based upon the national socialist concentration camp, to post-communist depositional literature reveals two focal directions of imagological relevance: on the one hand, the points of similarity and difference of totalitarian practices in creating stereotypes, cultivating the sense of absolute antagonist otherness and promoting distorted ethnic, social and national images and, on the other hand, the particular contributions and limitations posed by the post-totalitarian depositional discourse in (re)-creating national and social (self-)images.
\end{abstract}

Keywords: totalitarianism, distorted (self-)images, depositional literature, the witness

\section{Introduction}

Both national-socialist totalitarianism and later communist totalitarianism, although founded on divergent doctrines, relied on cultivating the sense of absolute antagonist otherness, materialised in stereotypical images and absolute discrimination: while Nazism brought race discrimination to its extreme, Communism followed the very same path in promoting extreme class segregation. The distorted racial, ethnic, and social images hereby created were then used as the foundation principles for the systematic extermination or annihilation of the segregated group. Harboured apparently by distinct ideologies, these two totalitarian extremes are, however, 
similar in two basic points: both were advocating a certain type of supremacy ${ }^{1}-$ race supremacy and class supremacy, respectively; both aimed at creating a new superior man, and for this purpose they coined iconic images, the image of the Arian superhuman of Nazism and the image of the New Man of Communism. In the name of this supremacy, both considered themselves entitled to eliminate the remnant minorities. The extermination plans were carried out in an organised manner in both cases, systematically eliminating the undesired other in concentration camps or in political prisons. Most victims perished leaving little evidence or just mere images behind. One is the image of the Muslim, ${ }^{2}$ the emaciated creature of the concentration camp, and the other image is that of the Re-educated ${ }^{3}$-the crippled, mutilated, and disfigured political detainee of the communist prison. Despite the very low survival rates ${ }^{4}$ in both cases, there are testimonies brought by the very bearers of those names. The Muslim of Auschwitz and the Re-educate of Piteşti meet in the realm of witness literature to utter the word for that image, to tell and to explain, to share the experience of a path leading up to the limit of almost everything. This testimony, of the limits of human existence and resistance reflects in its turn, another image, that of the unbelievable human potential. Although most testimonies were silenced definitively before being told, the merely exceptional survivors of both totalitarian extermination experiments have been able to provide accounts of the circumstances and specificity of each of them.

\section{Testimony, history, literature}

More than twenty years since the so-called implosion of the communist totalitarianism in Romania, contemporary historiography has the rather difficult task of performing a cautious selection of the sources usable in (re)writing the recent national history that has been subjected to substantial misrepresentation, programmatically orchestrated by the totalitarian regime until the revolution in 1989 (Boia 2012). Both national images and self-images have been directly related to literature and history, which, in turn, are mediated by historiography, the latter bearing the responsibility of wisely using the available literary-historical

1 Constructed by providing and cultivating distorted images, and creating stereotypes as to serve their purpose.

2 Muslim - term used in the concentration camp jargon to describe the prisoners that were in worst condition, emaciated, ill, voided of any will power, closest to death; used along with other parallel terms: in Dachau Kretiner [cretin], in Stuthof Kruppel [cripple], in Mauthausen Schwimmer [swimmer], in Neuengamme Kamele [camel], in Buchenwald müde Scheichs [tired sheik], in Ravensbruck Muselweiber [Muslim woman] or Schmuckstücke [jewel] (Sofsky 1993, 464).

3 Term used to refer to communist political detainees that were subjected to torture, mutilation, and disfigurement in the re-education process.

4 Various figures have been advanced so far, but are irrelevant to the objective of the underlying article, which does not intend to let itself entangled in the polemics of competitive victimhood. 
documentary resources. Among several other types of historical sources, not available in the context of totalitarian communist rule, yet highly relevant for attaining such an objective, there is this specific segment of written literature (Cesereanu 2005), currently referred to under a series of different denominations, such as witness literature, depositional literature, testimonial literature, literature of the Romanian Gulag, detention literature, prison memoirs, basically encompassing the totality of referential productions, written by opponents to the communist regime, a vast majority of them former political detainees (Cistelecan 2007).

\section{The New Man}

Communism has apparently learned from the radical lesson of national socialism, and has adapted its practices, placing a new landmark on the map of totalitarian cruelty, by the experiment of annihilating the human being while still alive ${ }^{5}$ - known under the name of re-education (Ierunca 1993). Whereas the surviving witness of the Nazi concentration camp is an unintended and unforeseen exception to the gruesome plan of extermination, communism planned to maintain the re-educated alive, ${ }^{6}$ to bear witness both to his own complete annihilation and to that of his peers, in the apotheosis of the creation of the New-communist-Man (Andreica 2007).

The destruction plan went this time in the direction of systematic and complete mental, physical and spiritual demolition of the individual, but keeping the victim alive was important, so as to document to what extent an individual can be bereft of his own humanity and substituted by a matrix consisting exactly of its opposite. In this respect, the testimony of re-education is the account of the human being, compelled to acquire a new countenance, a (self-)image that he or she will never be able to face. It is the testimony of the human being who had to wear Gorgon's face, and completely relinquish his own. And live with it, in addition to that.

This re-education experiment of communism is, therefore, the focal and starting point of the present paper, which aims at investigating the role of testimony in this particular instance of European totalitarianism of the past century, regarding its capacity to render an accurate account of the goals and practices used in creating that New Man.

The image of the communist ideal, paralleled to the current (self-)images of the post-communist individual is able to reveal to what extent the New Man has been created, and in what way some of his features are still traceable in the (self-)image of the contemporary post-communist individual.

5 That is the point of coincidence between the two experiments, attaining complete demolition of the human being while still alive, as presented by the symbolic figures of the Muslim of the concentration camp, on the one hand, and the re-educated of the communist prison, on the other. Making the re-education subject's escape from torture by suicide practically impossible. 


\section{Re-education}

Re-education was an experiment implemented in several Romanian prisons in the late 1940s, involving political detainees, mostly students, included in a category referred to by the stereotypical expression "enemies of the people," a label applied to all opponents of the communist party (Bacu 1989). They were arrested, usually for the fault of having been members of different other political groups prior to the instauration of the communist regime. Many of them were killed in the terrible tortures of the inquiry procedures. The rest were sentenced to long years of imprisonment and hard labour in mock trials, where no proof of their crimes was needed, where everything was a mere formality, in a court of law that was submissive to any political command (Rădulescu 1998).

The experiment itself aimed at creating a new individual, turning a political opponent into a fervent supporter by brainwashing the victims in gruesome torture. There is nothing new in that. The novelty, however, consists in the principles devised for this re-education: the victims were tortured to relinquish, in a first stage, all their personal beliefs, relationships, to denunciate and declare loath for their families, friends and mentors; then they were compelled by another set of torture techniques to make formal statements bringing terrible offences to themselves-admitting guilt to any crime or sin possible-, imprecations and offences to family, friends, mentors, to every personal belief, to God-basically to everything that was relevant and defining to them as human beings (Wurmbrand 1994). In short, they were compelled by torture, mutilation and disfiguration of the physical body to accept and perform themselves a much more horrifying type of torture: the mutilation of their souls, of their identity, and herewith to perform themselves the disfiguration of their conscience and of their spirit. Once the victim was considered re-educated, he was supposed to prove the truthfulness of his re-education by inflicting the same tortures, the very same mutilations of body and spirit upon their prison companions, upon their friends (Petrişor 1994). In case of resistance, they had to go through the initial re-education stages again. If he was not truly applying the torture procedures indicated, by faking or trying to spare the other the suffering, again he as well as his protégé had to go through the initial stages once again. There was not much choice in this situation. The closest relationships were dissolute in this manner, trust in others, but above all, the trust in oneself became empty words that did not allow meaning. Loathing everyone, starting from the communist torturers, the friends turned into one's torturers, and most painful of all, loathing oneself for becoming a torturer of best friends-that is the path towards the loss of one's humanity. 
It is this perverse sense of making the victim turn into the torturer, ${ }^{7}$ under the threat of relentless torment, and the absolute impossibility to escape by suicide, ${ }^{8}$ that made the experiment to be seen as one of the most barbaric ones in recent European history. ${ }^{9}$ Cultivating a sense of otherness towards the unknown stranger has been done before. Cultivating a sense of antagonist otherness towards the closest peer is not as common, but has also been done before. Cultivating a sense of antagonist otherness towards one's own self has been so far the subject of pathology. So far meaning up to the point when re-education made it possible for a human being to survive its own complete annihilation.

Just like the extermination within the concentration camp has become the symbol of Nazism, re-education becomes not only an experiment orchestrated in a number of Romanian prisons, but first and foremost, an emblematic image of communism. The historical relevance is therefore obvious, being another reason why the underlying analysis focuses on the testimony of re-education.

This experiment is simultaneously of imagological relevance, to the extent that it reveals, beyond its concrete and extreme practices, the very core of objectives and practices held by communist totalitarianism regarding the image and the identity of the individual it aimed to create. It provides an image of the intended New Man, which can be compared to the current image of the post-totalitarian individual, in an attempt to see what features of the latter have been actually seeded by the communist rule in over 50 years. It also provides a clear image of the way communism cultivated general mutual distrust, fear, and the sense of isolation that enabled it to preserve power for such a long amount of time.

\section{The new man after the New Man: (Self-)images of the post-communist individual}

The inconsistent evolution of post-totalitarian societies can be mainly attributed to a chronic perpetuation of the principles that generated the concept of New Man, as well as its various manifestations in less acute, attenuated, current forms that are, however, sufficient to compromise the possibility of a natural development of the individual and of the post-totalitarian society as a whole. The Individual, once again abandoned in the confusion of the obliteration of a

7 Becoming a torturer by torture not by free will, and becoming torturer of friends not of enemies, herewith making him the very author of his most painful torture, that of his conscience. While this ultimate way of escaping torment was still possible in the Nazi concentration camp: "Of course I could commit suicide, throwing myself over the barbed wire fence, I could do that anytime” (Sofsky 1993, 477).

9 So described by Aleksandr Solzhenitsyn, one of the most important literary witnesses of the Soviet Gulag. 
system of values (be it even an artificial and obtuse one), is repositioned in an environment lacking any landmarks, since both the old ones and the new ones have disappeared-the former systematically demolished by communism, and the latter obliterated by the final failure of the system.

The context disappears yet the reflexes persist-contrary to the Pavlovian predictions-and it is an undeniable fact that the individual of post-totalitarian society often sees himself placed in front of a mirror, reflecting the typological profile of the Re-educated New Man, subsuming all its inherent attributes: an original sin of cooperation or just the omission of denunciation-hereby indictable, especially before his own conscience, as accomplice and partner in crime to the totalitarian atrocities-; judged implicitly and explicitly, sentenced without the right to appeal by a new authority, that is equally culprit-and, hence, depleted of legitimacy; isolated within the narrow space of stigmatisation, blamed and feared by those from the outside the system; compelled to cohabitate with individuals similar to himself, yet enrolled in a new hierarchy that has little logic, is completely unjust and absolutely non-transparent; suspicious to the boundary of pathology; encouraged to acts of interior and exterior falsification; socially construed to alignment to the new rules of the game; adapted and engaged without his will in a competition with the single rationale of subsistence; the New Man exists; and just that. He cannot understand anything, he can do almost nothing and, above everything else, he cannot aspire towards anything. Looking forwards and behind, to his left and to his right: he is paralysed, trapped between options. He is voided, just like the old New Man, but he believes in nothing and he does not even want to. He builds nothing, is engaged in nothing but in the rationale of his own subsistence; he cannot and does not attempt to move on.

This new New Man of post-totalitarian society is trapped in his-not in the least enviable-status: simultaneously (denunciated and (self-)denunciated) as author and co-author of his own predicament (often referred to under the wellknown phrase "we deserve our fate"), yet also subjected to the quandary of the context hereby created (articulated in the cliché expression "the heavy heritage of communism")- the new man exists. And stands still.

Is this not the very portrait of the old New Man, the re-educated of totalitarianism, now drawn by the impressionist pencil on the recent page of geopolitics, that still bears the contours of the former picture, deeply imprinted by the sharp pressure of the totalitarian engraving tool? And if so, what next?

Two decades after the dissolution of the old regime, after undergoing a whole spate of re-configurations, attempts, experiments, re-considerations and more or less spectacular changes of route-some completely predictable, while some completely unexpected-it seems that the New Man has been created after all, and he persists. It seems that the predicament is not solved yet. Furthermore, contrary to all expectations placing their bets on an immediate and implicit realignment 
to the last coherent landmark, and a serene continuity of those coordinates, the solution is not even vaguely traceable at the line of the horizon.

The profile above, comprising all those current constituents of the postcommunist individual that can be traced back to the profile of the re-education victim, sums up a set of (self-)images common both to the internal and the external perception of the contemporary Romanian individual. Tracing back these features, their relation to some of the present difficulties society faces, may be useful for the awareness of their origin and possibly leads to finding ways to overcome them, by following the example set by the survivors of the literal and extreme re-education of the communist system.

What is left is a new man, disfigured and disoriented, simultaneously victimised object, yet also culprit subject for the past experiences, but especially for the recent ones, although apparently paralysed and enslaved by condemnable passivity, without very apparent manifestations, who is, however, looking for a solution. Maybe 'is looking' is too much to say. Maybe a more precise quantification should be expressed in other terms: This new man of contemporary post-communist society does not look for, but he awaits, maybe not to find, but to be shown, the solution. The first step in identifying any potential solution is to reconfigure the position of knowledge and comprehension, which become crucial for becoming aware of all aspects that contributed to the current context.

\section{Witness literature}

What better way is there, in attempting an identity reconfiguration, than initiating more involved research of the source and the course of this entanglement, profoundly affecting those who have experienced it, but also affecting younger generations by rebound totalitarianism. Hence, if transcending this profound fracture of identity becomes possible, by means of knowledge and awareness, then it is most certain that witness literature should be placed at the core of such endeavours.

However, looking back-once again-to the other instance of European totalitarianism of the twentieth century, the national-socialist regime, one can anticipate, by means of analogy, that an exact outline of the communist practices and their short and long term impact upon the individual will not be easily attainable due to the fact that totalitarianism, in all its forms, has proven extremely efficient in concealing its secrets—-the "arcana imperii" (Agamben 2006b, 11)—erasing the traces and leaving almost no witnesses behind. "Truly successful misdeeds leave no witnesses. It was only just possible to substantiate adequately the Nazi policy of annihilation. The black book of communism has large gaps" (Engdahl 2001, 5). The particular limitations posed by the post-totalitarian depositional discourse are due to a fourfold contextual predicament of this type of testimony. 
Thefirst-and mostgeneric-predicament oftestimony relies in the philosophical background ${ }^{10}$ undermining the concept of subjectivity itself by the destitution of the subject of its authority to interpret and confess "the historic experience of contemporary man" (Vattimo 1996, 70) as well as the historic experience in itself, totalitarianism, able to literally eliminate testimony—or most of it—by the programmatic and literal extermination of the witnesses. A second impediment is the programmatic erasure of all potential proof or documentation of the events by disposing of and replacing any person or material that can be used against the perpetrating totalitarian power. It is the "horror over the systematic erasure of memory in totalitarian societies" (Engdahl 2001, 6) that grants testimony the key position in the context of contemporary literary discourse. The third difficulty is rendered by the fact that the type of experience poses limitations of itself: the experiences "characterized by the most profound torment" (Engdahl 2001, 11) typical for the circumstances of the concentration camp, or the communist political prison are rather difficult and sometimes impossible to recall. Memory plays a central role in this respect, but in extreme situations oblivion becomes an instinctual reflex of the human set in survival mode.

This leads to the last obstacle in the way of testimony about totalitarianism, namely the fact that in both instances a vast majority of the potential witnesses are not left alive and can, therefore, not testify. The survivor of the totalitarian experiment has to testify both for himself and for the majority of his peers who have passed and are thus reduced to silence. The incapacity of the survivor to account for the experience of another, who has undergone the complete experience up to the end, is denominated in current criticism as the "lacuna of testimony" (Agamben 2006a, 7). There are, indeed, only a few surviving witnesses of the concentration camp and of the communist prison, when compared to the huge number of potential witnesses who have perished in these experiments. However, it is this very impairment that only places more emphasis upon those few witnesses that survived, upon those testimonies that can be shared. The experience of the totalitarian experiment has led, indeed, most of its victims to the end. To the end of their lives and simultaneously to the end of their humanity.

\section{The Complete Witness}

The complete experience of this path, up to its end is made by a vast majority, whereas the surviving witness acknowledges his exceptional status in having survived. A surviving witness is Primo Levi, who in his attempt of bringing his testimony of the concentration camp is faced with his incapacity of testifying for

10 Initiated by Nietzsche in his critique to the notion of consciousness as supreme instance of personality, and continued by Heidegger in questioning authenticity as a whole. 
the experience of the majority, since he himself did not make it, not "to the very end" (Wiesel 1975, 314). To account for this incapacity of revealing the fate of another, ${ }^{11}$ Levi appeals to an image as a symbol for the complete witness-the one who experienced the end in the camp but is, hence, in impossibility of bringing his own testimony-the image of the Muslim. Muslim was one of the terms used by camp jargon to describe those emaciated figures that were lingering on the boundary between life and death, "living corpses" (Agamben 2006a, 29), who will never be able to speak in the language of testimony:

An anonymous and continuously renewed but always the same mass of non-people, who march and labor in silence, in whom the divine spark has gone out, too empty of everything they had to actually suffer. One finds it difficult to call their death a death, they do not fear it, being too exhausted to be aware of anything. They stick to my memory in their faceless presence, and if I were to sum up all the evil of our time in an image, I would choose this image so familiar to me. (Levi 2004, 145)

Complete testimony is, hence, forever trapped in impossibility since the complete witness can never return to testify. While the complete witness-both in the sense coined by Primo Levi as well as in Giorgio Agamben's subsequent analysis-is exclusively the Muslim, the last page of Agamben's study brings forth an exceptional case, that is yet powerful enough to imply the reconfiguration of all operating concepts of the analysis: the existence of the testifying Muslim. There is indeed an existing corpus of direct testimonies brought by survivors both of the camp, but also survivors of the Muslim condition, coined as the point of loss of humanity, the point of non-humanity. The Muslim conditionup to this point, seen as the attribute but also the impossibility of complete testimony-is overcome by the surviving Muslim, hereby annulling part of the lacuna of testimony, namely the impossibility of complete testimony. A section of a monographic study of the Muslim provides, under the heading "I Was a Muslim” (Ryn and Klodzinski 1987, 128), testimonies of former Muslims, who not only survived but were able to recover from the non-human condition, and to return to humanity; they can bring the testimony of that limit: the loss of humanity. "Regarding their being prepared to die, however, there was nothing like an act of will, but rather a destruction of will. They let it come, because all of their strengths were mutilated and annihilated" (Kogon 1995, 400). The first person, past tense account of Muslims, "the non-humans" (Levi 2004, 146), brings complete testimony in the realm of possibility, and presents therein the

11 In a common statement made by many survivors of both totalitarian experiments: "I have said this before and I will not cease to say it: prison was not easy, but I suffered less than others, who would have far scarier things to testify" (Orlea 1991, 5). 
experience undergone up to its very limit, up to the end of humanity. It is this aspect that becomes of major relevance to the discourse of literary testimony since it allows a glimpse into the limit of human experience.

Applying this conceptual pattern, of the structure and contents of testimony, to the other instance of totalitarian experimentation, reveals new meanings of the re-education testimony. The account of witnesses having experienced reeducation is no longer a mere representation of torture and mutilation inflicted by the communist regime upon its political opponents. It is the complete exhibition of the human torment undergone by those who were pushed to their limits: in this case they were pushed to counter-humanity, in being forced to become the exact opposite of what they had been before. And there is, similar to the complete testimony of non-humanity ${ }^{12}$ of the Nazi concentration camp, also another instance of complete testimony of counter-humanity brought by the survivors of the communist re-education, where all victims were torturers and vice-versa, of others and of their own selves. An intricate design, one must admit. Intricate is the design still, since many of the principles are recognisable in the contemporary individual, as shown above. That only leads to the conclusion that re-education has been exported from the communist political prison to the outside world of the larger prison of the whole country applying the same principles with the softer gloves of later policies of the totalitarian party. The testimony of the more extreme experience has been useful in outlining the general image of the background as well as the details of the experiment.

\section{Conclusion}

Put into simpler words, the specificity of totalitarian experiments is that they bring the testimony of an experience of limit situations, where humanity is pushed to its extremes. The testimony on totalitarianism circumscribes a multitude of sequences in the line of de-humanisation of man, subjected to totalitarian power, a man who survives and brings, as witness, the testimony of the entire course of de-humanisation and even of its limit. Therefore, witness literature allows the unmediated encounter with humanity itself, in its most extreme but defining conditions: the perpetual denial and acknowledgement of its own destructibility, and everything that fits in between, ultimately resulting in an image of the unbelievable recovery resources of human potential.

12 The concept was initially coined by Primo Levi, and further investigated, among others, by the Italian critic and philosopher Giorgio Agamben referring to the testimony of undergoing the complete experience of the concentration camp, up to its limit set at the very boundary between life and death, between human and non-human. 


\section{Works cited}

Andreica, Gheorghe. 2007. Reeducările comuniste. Volumul I: Eugen Țurcanu, ruşinea speciei umane. [Communist Re-education. Volume I: Eugen Țurcanu, the Shame of the Human Species.] Constanța: Editura Ex Ponto.

Agamben, Giorgio. 2006a. Ce rămâne din Auschwitz. Arhiva şi martorul. [Remnants of Auschwitz. The Archive and the Witness.] Trans. Alexandru Cistelecan. Cluj: Ed. Idea Design \& Print.

-. 2006b. Homo Sacer. Puterea suverană şi viața nudă. [Homo Sacer. Sovereign Power and Bare Life.] Trans. Alexandru Cistelecan. Cluj: Ed. Idea Design \& Print.

Bacu, Dumitru. 1989. Piteşti. Centru de reeducare studențească. [Piteşti. Student Re-education Center.] Hamilton: Editura Cuvântul Românesc.

Boia, Lucian. 2012. Capcanele istoriei. Elita intelectuală Românească între 1930 şi 1950. [The Traps of History. The Romanian Intellectual Elite between 1930 and 1950.] Bucureşti: Ed. Humanitas.

Cesereanu, Ruxandra. 2005. Gulagul în conştiința românească. Memorialistica şi literatura închisorilor şi lagărelor comuniste. [The Gulag in the Romanian Conscience. Memoir Literature and the Literature of Communist Prisons and Camps.] Bucureşti: Ed. Polirom.

Cistelecan, Alexandru. 2007. Aide-Mémoir. Aspecte ale memorialisticii româneşti. [Aide-Mémoir. Aspects of Romanian Memoir Literature.] Braşov: Ed. Aula.

Engdahl, Horace. 2001. Philomela's Tongue. Introductory Remarks on Witness Literature. In Witness Literature: Proceedings of the Nobel Centennial Symposium, ed. Horace Engdahl, 1-14. Stockholm: World Scientific Publishing Co. Pte.

Ierunca,Virgil. 1993. Subiect şi predicat. [Subject and Predicate.] Bucureşti: Ed. Humanitas.

Kogon, Eugen. 1995. Der SS-Staat. Das System der deutschen Konzentrationslager. [The SS-State. The System of the German Concentration Camp.] München: Heyne.

Levi, Primo. 2004. Mai este oare acesta un om? [Is This a Man?] Trans. Doina Condrea Derer. Iaşi: Polirom.

Orlea, Oana. 1991. Ia-ți boarfele şi mişcă! [Get Your Things and Move!] Interview by Mariana Marin. Bucureşti: Cartea Românească.

Petrişor, Marcel. 1994. Memorii II: Secretul Fortului 13. Reeducări si execuții. [The Secret of Fort 11. Re-educations and Executions.] Iaşi: Editura Timpul.

Rădulescu, Mihai. 1998. Istoria literaturii române de detenție - memorialistica reeducărilor [The History of Romanian Detention Literature - Memoirs of Reeducations.] vol. I, Bucureşti: Ramida.

Ryn Zdzislaw and Klodzinski Stanslav. 1987. An der Grenze zwischen Leben und Tod. Eine Studie über die Erscheinung des Muselmanns im Konzentrationslager. 
[At the Borderline between Life and Death. A Study of the Emergence of the Muslim in the Concentration Camp]. Auschwitz-Hefte, vol 1, Weinheim \& Basel: Beltz.

Sofsky, Wolfgang. 1993. Die Ordnung des Terrors. [The Order of Terror.] Frankfurt a.M: Fischer Taschenbuch.

Vattimo, Gianni. 1996. Aventurile diferenței. [The Adventure of Difference.] Trans. Ştefania Mincu. Constanța: Pontica.

Wiesel, Ellie. 1975. For Some Measure of Humility. Sh'ma: A Journal of Jewish Responsibility no. 5: 314.

Wurmbrand, Richard. 1994. Cu Dumnezeu în subterană. [With God in the Underworld.] Bucureşti: Editura Casa Şcoalelor. 